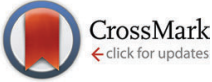

Cite this: New J. Chem., 2016, 40,6127

Received (in Victoria, Australia) 14th December 2015,

Accepted 5th May 2016

DOI: 10.1039/c5nj03556b

www.rsc.org/njc

\title{
Carbon-rich cyclopentadienyl ruthenium allenylidene complexes $\dagger$
}

\author{
Susanne Spörler, ${ }^{a}$ Frank Strinitz, ${ }^{a}$ Philipp Rodehutskors, ${ }^{a}$ Lisa Müller, ${ }^{a}$ \\ Andreas R. Waterloo, ${ }^{b}$ Maximilian Dürr, ${ }^{a}$ Eike Hübner, ${ }^{c}$ Ivana Ivanović-Burmazović, ${ }^{a}$ \\ Rik R. Tykwinski and Nicolai Burzlaff*a
}

\begin{abstract}
Ruthenium allenylidene complexes with carbon-rich polyaromatic moieties have been synthesized by using $\left[\mathrm{RuCl}\left(\eta^{5}-\mathrm{C}_{5} \mathrm{H}_{5}\right)\left(\mathrm{PPh}_{3}\right)_{2}\right]\left(\eta^{5}-\mathrm{C}_{5} \mathrm{H}_{5}=\right.$ cyclopentadienyl) as a precursor and the propargyl alcohols 10-ethynyl-10-hydroxyanthracen-9-one (ACO), 13-ethynyl-13-hydroxypentacen-6-one (PCO), 1-phenyl-1(pyren-1-yl)prop-2-yn-1-ol (PyrPh), 9-ethynyl-9H-fluoren-9-ol (FN) and 6-ethynyl-6H-benzo[cd]pyren-6-ol (BPyr) as ligands. The resulting cationic allenylidene complexes, $\left[R u\left(\eta^{5}-C_{5} H_{5}\right)(=C=C=(A O))\left(P^{2} h_{3}\right)_{2}\right] P F_{6}(\mathbf{1})$, $\left.\left[\mathrm{Ru}\left(\eta^{5}-\mathrm{C}_{5} \mathrm{H}_{5}\right)=\mathrm{C}=\mathrm{C}=(\mathrm{PCO})\right)\left(\mathrm{PPh}_{3}\right)_{2}\right] P F_{6} \quad(\mathbf{2}), \quad\left[\mathrm{Ru}\left(\eta^{5}-\mathrm{C}_{5} \mathrm{H}_{5}\right)(=\mathrm{C}=\mathrm{C}=(\mathrm{PyrPh}))\left(\mathrm{PPh}_{3}\right)_{2}\right] \mathrm{PF} F_{6} \quad(\mathbf{3}), \quad\left[\mathrm{Ru}\left(\eta^{5}-\mathrm{C}_{5} \mathrm{H}_{5}\right)-\right.$ $\left.(=\mathrm{C}=\mathrm{C}=(\mathrm{FN}))\left(\mathrm{PPh}_{3}\right)_{2}\right] \mathrm{PF} 6 \quad(\mathbf{4})$, and $\left[\mathrm{Ru}\left(\eta^{5}-\mathrm{C}_{5} \mathrm{H}_{5}\right)(=\mathrm{C}=\mathrm{C}=(\mathrm{BPyr}))\left(\mathrm{PPh}_{3}\right)_{2}\right] \mathrm{PF}_{6} \quad$ (5) show interesting intermolecular $\pi$-interactions in the solid-state structure as well as solution state complexation with pyrene (documented by Job's plots experiments). CV data indicate possible Ru(II)/Ru(III) oxidation, as well as the potential reduction of the carbon-rich allenylidene moiety.
\end{abstract}

\section{Introduction}

In recent years, there has been great interest in bringing metal complexes in close contact with single-wall carbon nanotubes (SWCNTs). Apart from covalent attachment, $\pi$-interactions of SWCNTs with polyaromatic moieties, such as pyrene or diazaacenes, could lead to applications in catalysis, photoinduced electron transfer or information storage. ${ }^{1-3}$

Moreover, various acene derivatives and their precursors, the acenequinones, are promising candidates for small-molecule semiconductor applications and have been studied regarding their potential applications in thin film transistors. ${ }^{4-6}$ Even anthraquinones and pentacenequinones are, like the anthracenes and pentacenes, potentially useful organic semiconductors, although their applications as organic semiconductors remain largely unexplored. $^{4-8}$ The derivatization or functionalization of acenes is mostly achieved by attaching alkyl, aryl, and alkyne residues at the middle of the acene framework in order to tune the HOMOLUMO gap. Furthermore, these residues can have an influence on

\footnotetext{
${ }^{a}$ Inorganic Chemistry, Department of Chemistry and Pharmacy, Friedrich-Alexander University Erlangen Nürnberg (FAU), Egerlandstraße 1, 91058 Erlangen, Germany. E-mail: nicolai.burzlaff@fau.de; Fax: +49913185 27387; Tel: +49 91318528976 ${ }^{b}$ Organic Chemistry, Department of Chemistry and Pharmacy, Friedrich-Alexander University Erlangen Nürnberg (FAU), Henkestraße 42, 91054 Erlangen, Germany. E-mail: rik.tykwinski@fau.de; Fax: +49 913185 26865; Tel: +49 91318522540 ${ }^{c}$ Organic Chemistry, Technical University Clausthal, Leibnizstraße 6,

38678 Clausthal Zellerfeld, Germany

$\dagger$ Electronic supplementary information (ESI) available: Job's plots, CSI-MS, CV, UV/Vis and X-ray data of 1, 2 and 5. CCDC 1406943, 1406944 and 1417389. For ESI and crystallographic data in CIF or other electronic format see DOI: 10.1039/c5nj03556b
}

the acene arrangement in the solid state, e.g. regarding the manner of the $\pi$-stacking. . $^{4,9-11}$

Ruthenium carbon-rich allenylidene complexes with polyaromatic substituents have the ability to exchange electrons via the allenylidene unit, which might lead to a variety of applications like magnetic and optical devices. ${ }^{12-17}$ Since its first examples reported independently in 1976 by Fischer ${ }^{18,19}$ as well as by Berke $^{20}$ the chemistry of transition metal allenylidene complexes increased significantly due to their promising chemical and physical properties and has been reviewed extensively by various authors. ${ }^{14,21-26}$ Transition metal allenylidene complexes turned out to be interesting and useful complexes and intermediates for a huge range of chemistry and catalytic processes. ${ }^{23,27-29}$ Especially, the building block properties of allenylidene complexes in organic syntheses as well as their catalytic properties, for example as catalysts or pre-catalysts for the olefin metathesis, ${ }^{30-38}$ arouse interest. Other reports focus on the esterification of propargyl alcohols ${ }^{39}$ or the ring opening polymerization. ${ }^{40-43}$ Usually, electrophiles add to $\mathrm{C}-\beta$ of the allenylidene moieties, affording cationic carbyne complexes, ${ }^{44}$ whereas nucleophiles attack at $\mathrm{C}-\alpha$ or $\mathrm{C}-\gamma^{27,45-48}$

Recently, we reported on ruthenium allenylidene complexes $\left[\mathrm{Ru}(\right.$ bdmpza $\left.) \mathrm{Cl}\left(\mathrm{PPh}_{3}\right)\left(=\mathrm{C}=\mathrm{C}=\mathrm{CR}_{2}\right)\right]($ bdmpza $=$ bis(3,5-dimethylpyrazol-1-yl)acetate; $=\mathrm{CR}_{2}=$ polyaromatic residue) bearing polyaromatic moieties. ${ }^{4-51}$ Most of these complexes show strong $\pi$-stacking interactions in solid state, which could be, therefore, promising candidates for metal-tuned FETs or "organic" metalsemiconductor field-effect transistors (OMESFETs). The synthesis followed the procedure first reported by Selegue ${ }^{52}$ by using the 
corresponding propargyl alcohols. It is worthwhile mentioning that Fürstner et al. reported on a series of cationic ruthenium allenylidene complexes of the type $\left[\left(\eta^{6}-(p\right.\right.$-cymene $\left.)\right)\left(\mathrm{R}_{3} \mathrm{P}\right)$ $\left.\operatorname{RuCl}\left(=\mathrm{C}=\mathrm{C}=\mathrm{CR}_{2}{ }^{\prime}\right)\right]^{+} \mathrm{X}^{-}$gained by a Selegue type reaction. ${ }^{23}$ Moreover, other cationic $\mathrm{Cp}$-ruthenium allenylidene complexes such as $\left[\mathrm{Ru}\left(\eta^{5}-\mathrm{C}_{5} \mathrm{H}_{5}\right)\left(\mathrm{PPh}_{3}\right)_{2}\left(=\mathrm{C}=\mathrm{C}=\mathrm{CR}_{2}\right)\right] \mathrm{PF}_{6}$ are also wellknown for almost two decades ${ }^{53,54}$ and therefore, spark our interest. Thus, here we report on cationic cyclopentadienyl allenylidene complexes $\left[\mathrm{RuCl}\left(\eta^{5}-\mathrm{C}_{5} \mathrm{H}_{5}\right)\left(\mathrm{PPh}_{3}\right)\left(=\mathrm{C}=\mathrm{C}=\mathrm{CR}_{2}\right)\right]^{+}$ with various carbon-rich polyaromatic moieties $\left(=\mathrm{CR}_{2}\right)$.

\section{Results and discussion}

The synthesis of the allenylidene complexes followed the procedure first reported by Selegue ${ }^{52}$ by using the corresponding propargyl alcohols as building blocks. 10-Ethynyl-10-hydroxyanthracen-9-one (AO), 13-ethynyl-13-hydroxypentacen-6-one (PCO), 1-phenyl-1-(pyren1-yl)prop-2-yn-1-ol (PyrPh), 9-ethynyl-9H-fluoren-9-ol (FN) and 6-ethynyl-6H-benzo[ $c d]$ pyren-6-ol (BPyr) have been chosen as starting materials. These precursors were reacted with $[\mathrm{RuCl}-$ $\left.\left(\eta^{5}-\mathrm{C}_{5} \mathrm{H}_{5}\right)\left(\mathrm{PPh}_{3}\right)_{2}\right]$ and $\mathrm{NH}_{4}\left[\mathrm{PF}_{6}\right]$ in $\mathrm{MeOH}$ for one to two days (Scheme 1) to obtain the deep colorful allenylidene complexes after removal of the solvent, recrystallisation from $\mathrm{CH}_{2} \mathrm{Cl}_{2} / \mathrm{Et}_{2} \mathrm{O}$ and subsequent purification via column chromatography (silica; $\mathrm{CH}_{2} \mathrm{Cl}_{2}$ /acetone).

The resulting mono-cationic complexes are rather stable towards oxygen and were characterized by ${ }^{1} \mathrm{H},{ }^{13} \mathrm{C}$ and ${ }^{31} \mathrm{P}$ NMR spectroscopy, IR spectroscopy, ESI mass spectrometry and elemental analysis. Crystals suitable for X-ray structure determinations were obtained of 1, 2 and 5 (Fig. 1).

The structures of the complexes 1, 2 and 5 exhibit similar bond figure lengths and angles referring to the allenylidene unit and the anthraquinone, the pentacenequinone and the benzopyrene moieties (Table S2, ESI $\dagger$ ). The angle between $\mathrm{Ru}-\mathrm{C}_{\alpha}-\mathrm{C}_{\beta}=168.7^{\circ}$ of complex 2 is more bent in comparison to $\angle \mathrm{C}_{\alpha}-\mathrm{C}_{\beta}-\mathrm{C}_{\gamma}=172.1^{\circ}$ for $\mathbf{1}$ and $176.2^{\circ}$ for 5 , which could be the consequence of the staircase $\pi$-stacking (see below). However, these angles are closer to the ideal $180^{\circ}$ compared to the recently reported complex $\left[\mathrm{Ru}(\right.$ bdmpza $\left.) \mathrm{Cl}\left(\mathrm{PPh}_{3}\right)(=\mathrm{C}=\mathrm{C}=(\mathrm{PCO}))\right] .{ }^{49-51,55}$ The $\mathrm{C}_{\alpha}-\mathrm{C}_{\beta}$ bond lengths (1.251 $\mathrm{\AA}(\mathbf{1}) ; 1.256 \AA$ (2) and $1.250 \AA$ (5))

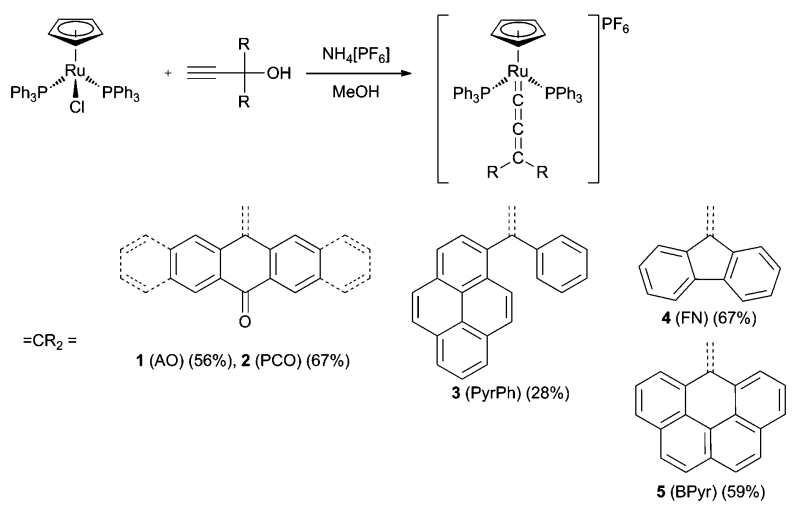

Scheme 1 Synthesis of mononuclear ruthenium allenylidene complexes $1-5$. a)

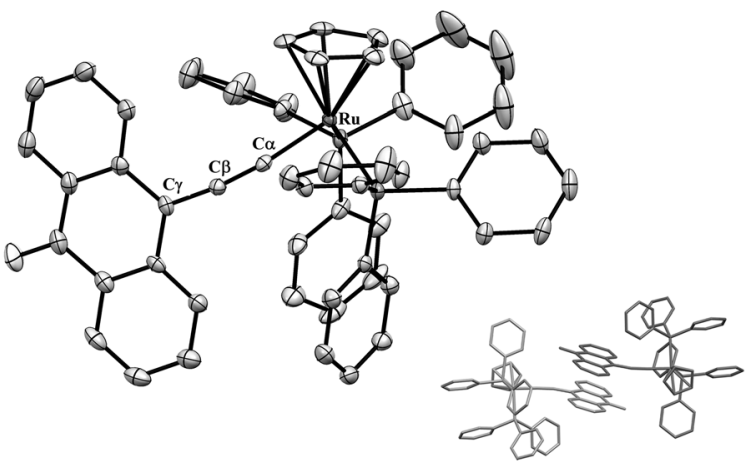

b)

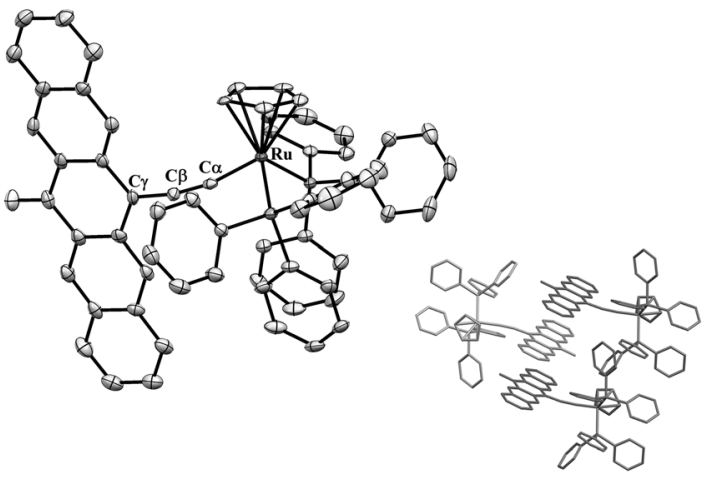

c)

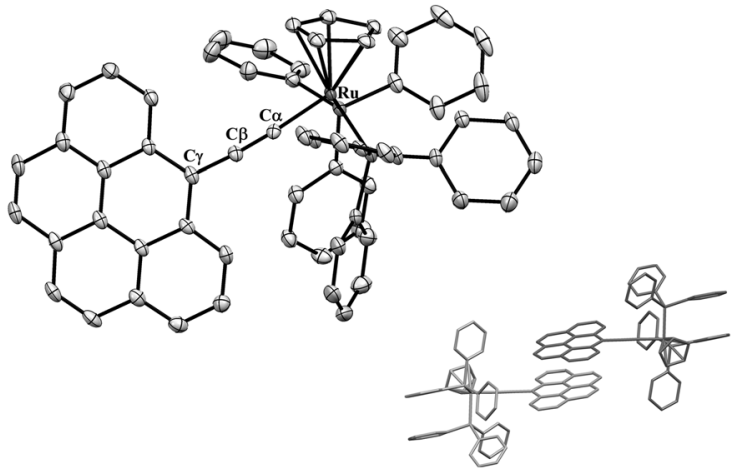

Fig. 1 Molecular structures of 1, 2 and 5. $\pi$-Stacking (3.38 $\AA$ ) resulting in (a) formation of a dimer for $\mathbf{1}$, (b) a staircase for $\mathbf{2}$ packing (3.37 and $3.39 \AA$ ) along the pentacenequinone axis (three molecules are shown) while (c) no $\pi$-stacking is observed for $\mathbf{5}$. The hexafluorophosphate anions, solvent molecules and hydrogen atoms have been omitted for clarity.

and the $\mathrm{C}_{\beta}-\mathrm{C}_{\gamma}$ distances (1.356 ̊ (1), $1.360 \AA$ (2) and $1.378 \AA$ (5)) are typical for the allenylidene unit when compared to other published allenylidene complexes. ${ }^{14,21,49-51,55}$ The $\mathrm{Ru}-\mathrm{C}_{\alpha}$ bond distances of $1.895 \AA$ (1), $1.907 \AA$ (2) and $1.925 \AA$ (5) are in good agreement with the distances of $\mathrm{Ru}-\mathrm{C}$ cumulenylidene bonds. ${ }^{14,21,49-51,55}$

The experimental distances of the molecular structure of 2 are in good accordance to the theoretical values gained by DFT calculations (Table S2, ESI $\dagger$ ).

While the packing analysis of complex 1 exhibits the formation of dimeric units in the solid state due to $\pi$-stacking, the $\pi$-stacking of 2 causes the formation of a staircase arrangement with short interplanar distances of 3.39 and $3.37 \AA$ (Fig. 1). The pentacenone units are arranged by this face-to-face $\pi$-stacking, which typically comes along with some displacement along the molecular axis, 
to form this staircase packing. Thus, one of the common packing motifs adopted by semiconducting $\pi$-molecules is reflected in this crystal structure. As a result, complex 2 could represent a good design for n-type semiconductors in thin film transistors. It was also possible to investigate the aggregation of 1-5 with pyrene in solution, by UV/Vis titration experiments. The stoichiometry of the aggregation was determined by recording Job's plots. ${ }^{56}$ The plots of the complexes 3, 4 and 5 show maxima at $\chi=0.5$, which indicate the formation of $1: 1$ adducts in solution (Job's plots of 1 , 4 and 5 with pyrene: Fig. S1-S3, ESI $\dagger$ ). Moreover, also the graphs of the anthraquinone and pentacenequinone based complexes 1 and 2 seem to show maxima at $\chi=0.5$ at a first glance. But at a closer look, these graphs might point out local maxima at $\chi=0.4$ and $\chi=0.6$ (Fig. 2), which could indicate an equilibrium of $1: 2$ and $2: 1$ pyrene : complex adducts at the concentrations used for the titration experiments, besides the $1: 1$ adducts. A shoulder in the Job's plot of 5 at $\chi=0.8$ might also indicate the presence of $2: 1$ pyrene: complex adduct species.

To back these titration results, we then investigated the aggregation of the complexes $\mathbf{2}$ and $\mathbf{5}$ with pyrene via cryospray-ionisation mass spectrometry (CSI-MS). The data is in accordance with the conclusions drawn from the Job's plots measurements and indicate an $1: 1$ adduct in case of complex 2 and a $2: 1$ pyrene:complex adduct in case of 5, respectively (CSI-MS, see Fig. S4 and S5, ESI $\dagger$ ).

The cyclic voltammetric (CV) analysis of the complexes 1-5 reveals several ligand based reductions and one ruthenium-based oxidation for some of the complexes. For complexes 1, 3 and 4,
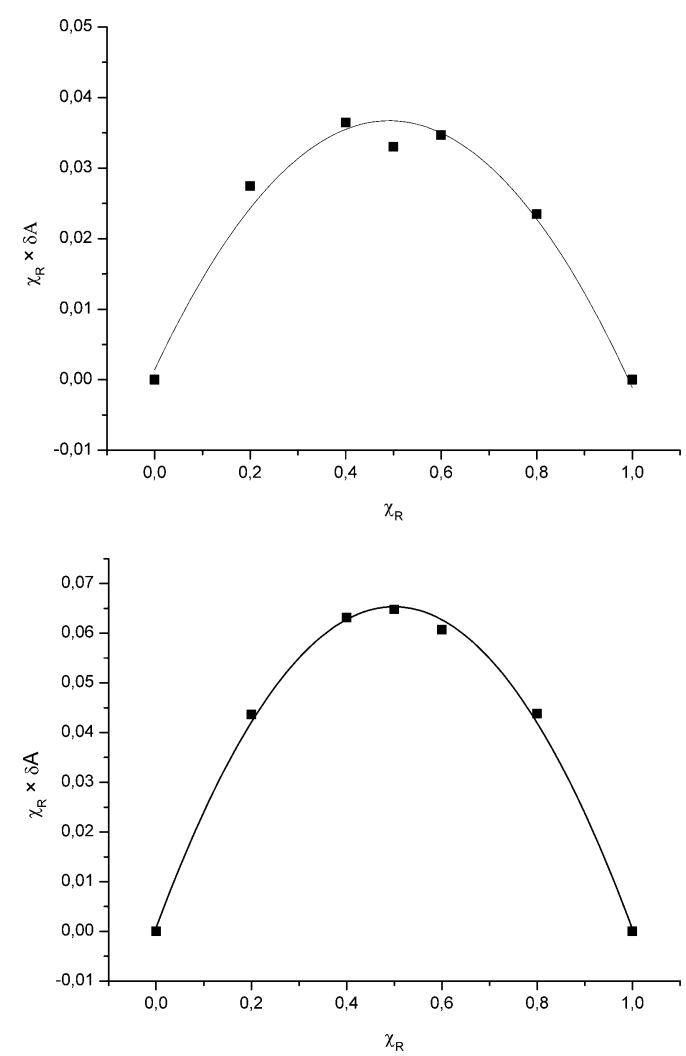

Fig. 2 Job's plots of the aggregation of 2 (top) and 3 (bottom) with pyrene. the $\mathrm{Ru}^{2+} / \mathrm{Ru}^{3+}$ couple shows either a reversible process or an irreversible event at about 0.50 to $0.60 \mathrm{~V}$ in the cyclovoltammogram. We ascribe this oxidation event to the $\mathrm{Ru}^{2+} / \mathrm{Ru}^{3+}$ redox couples due to previous observations for related carbon-rich allenylidene complexes reported by our group. ${ }^{49,50}$ Moreover, this assignment agrees well with those of other authors. ${ }^{57-59}$ In contrast, Skelton and Koutsantonis considered it unlikely that such oxidation processes may correspond to the $\mathrm{Ru}^{2+} / \mathrm{Ru}^{3+}$ oxidation couple but preferred a ligand-centered oxidation instead. ${ }^{60}$ Furthermore, they reported on irreversible ligand-centered oxidation processes around $1.4 \mathrm{~V}$. It is worthwhile mentioning that complexes 2-5 exhibit similar irreversible oxidations in the range of $1.25 \mathrm{~V}$ to $1.48 \mathrm{~V}$ which thus might also be ligand-centered.

However, for complex 2 and 5, two reversible processes at $-0.64 \mathrm{~V}$ and $-1.28 \mathrm{~V}$ and $-0.73 \mathrm{~V}$ and $-1.65 \mathrm{~V}$, respectively, correspond to the reduction of the organic moiety of the complex, i.e. the allenylidene unit bearing the pentacene or the benzopyrene moiety. Exemplary scans for complexes 2 and 5 are depicted in Fig. 3 (for full CV data of the complexes see Fig. S6-S10, ESI $\dagger$ ). Obviously, the complexes possess a significant electron-acceptor potential compared to PCBM ([6,6]-phenyl-C61butyric acid methyl ester), which is known as an excellent electron-acceptor (pristine PCBM exhibits three reduction peaks at $-1.11 \mathrm{~V},-1.33 \mathrm{~V}$, and $\left.-1.92 \mathrm{~V} v s . \mathrm{Ag} / \mathrm{Ag}^{+}\right) .{ }^{61}$ Thus, according to the observed reduction processes future application of complexes 2 and $\mathbf{5}$ as electron-acceptors might be possible. On the other hand suggest the observed (metal centered) oxidation processes electron donor properties for some of the complexes.

$\mathrm{UV} / \mathrm{Vis}$ spectra of the complexes were recorded in $\mathrm{CH}_{2} \mathrm{Cl}_{2}$ (Fig. 4 and Fig. S11-S15, ESI $\dagger$ ). All allenylidene complexes 1-5 show characteristic absorptions corresponding to MLCT transitions in the range of $400 \mathrm{~nm}$ to $700 \mathrm{~nm}$. Complexes 2, 3, and 5 exhibit rather intense absorption bands with extinction coefficients in a range of 20000 to $45000 \mathrm{~L} \mathrm{~mol}^{-1} \mathrm{~cm}^{-1}$ (Fig. 4 and 5).

Due to the nearly panchromic absorption and high extinction coefficients, the pentacenequinone, pyrenophenone and benzopyrenone-based complexes 2, 3 and 5 could represent promising dyes for dye-sensitized solar cells (DSSC). Furthermore, the allenylidene complexes show broad transitions at the edge of the NIR region, at about 900-1000 nm, which can be attributed to

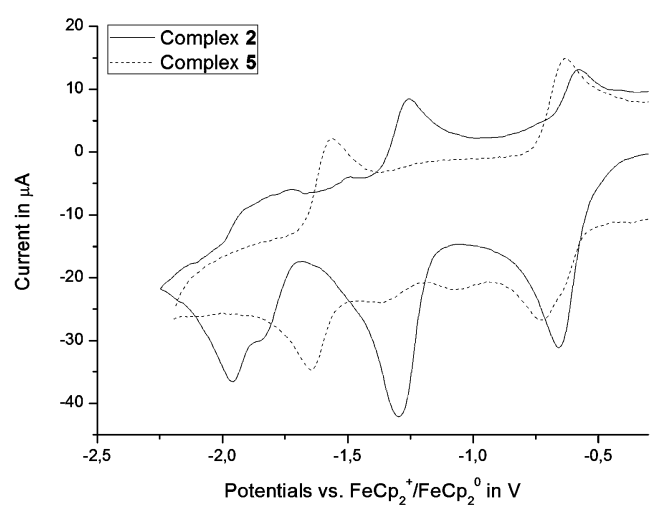

Fig. 3 Reductive part of the cyclic voltammogram of 2 and $\mathbf{5}(1.00 \mathrm{mM})$ in $n-\mathrm{Bu}_{4} \mathrm{NPF}_{6}(0.1 \mathrm{M})$ solution of $\mathrm{MeCN}$ at scan rate of $500 \mathrm{mV} \mathrm{s}{ }^{-1}$. 


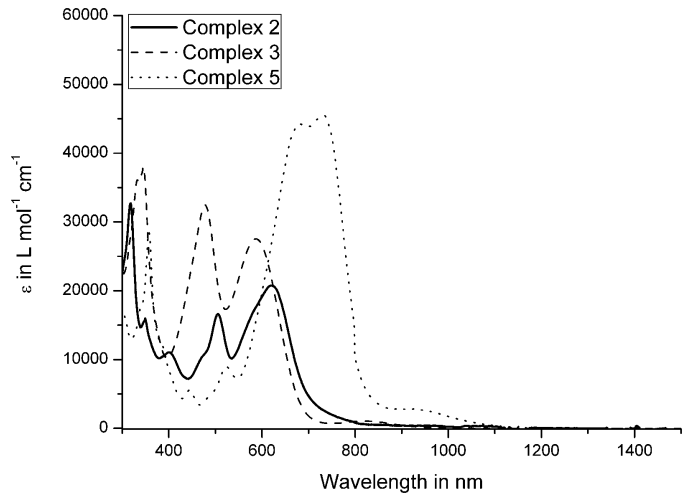

Fig. 4 UV/Vis absorption spectra of 2, 3 and $\mathbf{5}$ in $\mathrm{CH}_{2} \mathrm{Cl}_{2}(300-1500 \mathrm{~nm})$.

HOMO-1 $\rightarrow$ LUMO and HOMO $\rightarrow$ LUMO excitations. Surprisingly, UV/Vis measurements regarding complex 2 revealed no absorptions located in this region, which is in accordance to the TD-DFT calculations of the excited state of 2 . The transitions at lower wavelength of $\mathbf{3}$ and $\mathbf{5}$ are in good agreement with former TD-DFT calculations. ${ }^{49,50}$

\section{Experimental}

All air sensitive compounds were prepared under dry argon or nitrogen atmosphere using conventional Schlenk techniques. The yields refer to analytically pure substances. The starting compounds were used as purchased without further purification. The ${ }^{1} \mathrm{H},{ }^{13} \mathrm{C}$ and ${ }^{31} \mathrm{P}$ NMR were measured with either a Bruker AVANCE DPX300, a Bruker AVANCE DRX400 WB, a Bruker AVANCE III HD $400 \mathrm{MHz}$ spectrometer and a Bruker AVANCE III HD $600 \mathrm{MHz}$ spectrometer. The $\delta$ values are given in ppm relative to tetramethylsilane and were calibrated by the solvent peaks of the deuterated solvent. Electrospray-ionization MS (ESI-MS) measurements were performed on an UHR-TOF Bruker Daltonik (Bremen, Germany) maXis plus 5G, an ESI-ToF MS capable of resolution of at least 60000 FWHM. Detection was in positive ion mode, the source voltage was $2.8 \mathrm{kV}$. The flow rates were $180 \mu \mathrm{L}$ per hour. The drying gas $\left(\mathrm{N}_{2}\right)$, to aid solvent removal, was held at $180{ }^{\circ} \mathrm{C}$ and the spray gas was held at $20^{\circ} \mathrm{C}$. Cryosprayionization MS (CSI-MS) measurements were performed on an UHR-TOF Bruker Daltonik (Bremen, Germany) maXis plus 5G, an ESI-TOF MS capable of resolution of at least 60000 FWHM, which was coupled to a Bruker Daltonik Cryospray unit. Detection was in positive ion mode, the source voltage was $4.5 \mathrm{kV}$. The flow rates were $280 \mu \mathrm{L}$ per hour. The drying gas $\left(\mathrm{N}_{2}\right)$, to aid solvent removal, was held at $-35{ }^{\circ} \mathrm{C}$ and the spray gas was held at $-40{ }^{\circ} \mathrm{C}$. The machine was calibrated prior to every experiment via direct infusion of the Agilent ESI-TOF low concentration tuning mixture, which provided a $\mathrm{m} / \mathrm{z}$ range of singly charged peaks up to $2700 \mathrm{Da}$ in both ion modes. IR spectra were recorded with a Varian EXCALIBUR FTS-3500 FT-IR spectrometer in $\mathrm{CaF}_{2}$ cuvettes $(0.2 \mathrm{~mm})$ or in a $\mathrm{KBr}$ matrix. For elemental analysis, an Euro EA 3000 (Euro Vector) and EA 1108 (Carlo Erba) instrument were used. Thermogravimetric analyses (TGA) were achieved on a Mettler Toledo DSC 821e/Sensor FRS5-Ceramic.

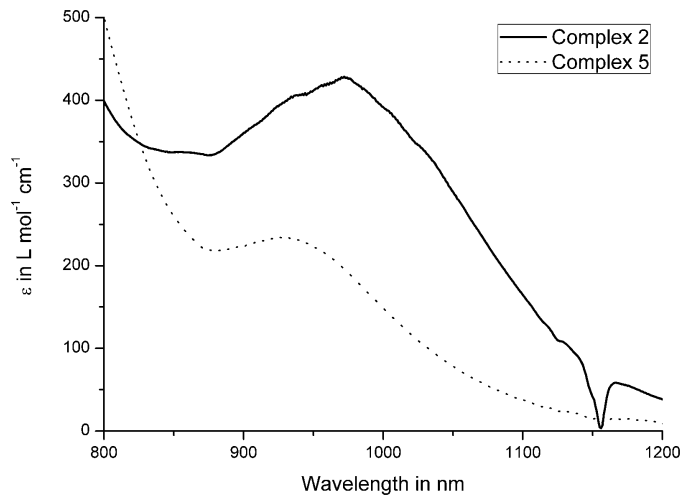

Fig. 5 UV/Vis-NIR absorption spectra of $\mathbf{3}$ and $\mathbf{5}$ in $\mathrm{CH}_{2} \mathrm{Cl}_{2}$ in the range of $800-1200 \mathrm{~nm}$.

All thermal analyses were carried out under a flow of nitrogen with a heating rate of $10{ }^{\circ} \mathrm{C} \mathrm{min}^{-1}$. Thermal decomposition temperature as measured by TGA (as sample weight loss) is reported as $T_{\mathrm{d}}$ in which the temperature listed corresponds to the intersection of the tangent lines of the baseline and the edge of the peak corresponding to the first significant weight loss, typically $>5 \%$. UV/Vis spectroscopy was performed with a Shimadzu UV-2401PC or a Varian Cary 5000 spectrometer. $\left[\mathrm{Ru}\left(\eta^{5}-\mathrm{C}_{5} \mathrm{H}_{5}\right) \mathrm{Cl}\left(\mathrm{PPh}_{3}\right)_{2}\right]{ }^{62}$ 10-ethynyl-10-hydroxyanthracen-9-one, ${ }^{49}$ 13-ethynyl-13-hydroxy-pentacen-6-one, ${ }^{50}$ 1-phenyl-1-(pyren-1-yl)prop-2-yn-1-ol ${ }^{55}$ and $6 H$-benzo $[c d]$ pyren-6-one ${ }^{63}$ were prepared according to the literature.

\section{Synthesis of 6-((trimethylsilyl)ethynyl)-6H-benzo[ $[c d]$ pyren-6-ol}

$n$-Butyllithium (1.95 mL, 1.6 M in hexanes, $3.12 \mathrm{mmol}, 8$ equiv.) was added dropwise to a solution of TMS-acetylene $(0.55 \mathrm{~mL}$, $3.90 \mathrm{mmol}, 10$ equiv.) in THF $(20 \mathrm{~mL})$ at $-50{ }^{\circ} \mathrm{C}$ under argon atmosphere. The mixture was warmed to room temperature and stirred for 45 minutes. $6 H$-Benzo $[c d]$ pyren-6-one $(100 \mathrm{mg}$, $0.394 \mathrm{mmol}$ ) was added as a solid in one portion and the resulting solution was stirred at room temperature for 14 hours. The reaction mixture was quenched by the addition of water $(5 \mathrm{~mL})$ and the solvent was removed in vacuo. The crude product was loaded on a column (silica, $\varnothing 4 \mathrm{~cm}$, length $10 \mathrm{~cm}$ ) and eluted with acetone/n-pentane $(1: 1, \mathrm{v} / \mathrm{v})$ to obtain the brown product $\left(R_{\mathrm{f}}=0.6\right)$ in yield of $128 \mathrm{mg}(0.241 \mathrm{mmol}, 93 \%) .{ }^{1} \mathrm{H}$ NMR $\left(300 \mathrm{MHz}, \mathrm{CDCl}_{3}\right): \delta=8.50\left(\mathrm{~d},{ }^{3} J_{\mathrm{H}, \mathrm{H}}=7.7 \mathrm{~Hz}, 2 \mathrm{H}, \mathrm{H} 3\right), 8.07$ $\left(\mathrm{d},{ }^{3} \mathrm{~J}_{\mathrm{H}, \mathrm{H}}=7.7 \mathrm{~Hz}, 2 \mathrm{H}, \mathrm{H} 5\right), 8.03\left(\mathrm{~d},{ }^{3} \mathrm{~J}_{\mathrm{H}, \mathrm{H}}=8.7 \mathrm{~Hz}, 2 \mathrm{H}, \mathrm{H} 7 / \mathrm{H} 8\right)$, $7.95\left(\mathrm{~d},{ }^{3} J_{\mathrm{H}, \mathrm{H}}=8.7 \mathrm{~Hz}, 2 \mathrm{H}, \mathrm{H} 7 / \mathrm{H} 8\right), 7.82\left(\mathrm{t},{ }^{3} J_{\mathrm{H}, \mathrm{H}}=7.7 \mathrm{~Hz}, 2 \mathrm{H}, \mathrm{H} 4\right)$, 0.26 (s, $9 \mathrm{H}, \mathrm{SiMe}_{3}$ ) ppm; ${ }^{13} \mathrm{C} \mathrm{NMR}\left(75 \mathrm{MHz}, \mathrm{CDCl}_{3}\right): \delta=137.2(\mathrm{C})$, 136.8 (C), $131.6(\mathrm{C}), 129.4(\mathrm{C}), 128.8(\mathrm{CH}), 127.9(\mathrm{CH}), 126.3(\mathrm{CH})$, $125.7(\mathrm{CH}), 124.2(\mathrm{C}), 106.6(\mathrm{C} \equiv \mathrm{C}), 93.0(\mathrm{C} \equiv \mathrm{C}), 68.9(\mathrm{C}-\mathrm{OH})$, $-0.1(\mathrm{Me})$ ppm; ESI-MS (MeOH) $m / z(\%)=531.13(30)[\mathrm{M}-\mathrm{H}]^{-}$; IR $\left(\mathrm{CH}_{2} \mathrm{Cl}_{2}\right): \tilde{\nu}=3258(\mathrm{~s}, \mathrm{OH}), 2948(\mathrm{~m}, \mathrm{CH}), 2114(\mathrm{w}, \mathrm{C} \equiv \mathrm{C}), 1617$ $(\mathrm{C}=\mathrm{C}), 1583(\mathrm{C}=\mathrm{C}) \mathrm{cm}^{-1}$; $\mathrm{EA} \mathrm{C}_{24} \mathrm{H}_{20} \mathrm{OSi}\left(352.51 \mathrm{~g} \mathrm{~mol}^{-1}\right)$ : calc.: $\mathrm{C}$ 81.78, H 5.72; found: C 81.43, H 5.77\%.

\section{Synthesis of 6-ethynyl-6H-benzo $[\mathrm{cd}]$ pyren-6-ol}

6-((Trimethylsilyl)ethynyl)-6H-benzo[ $c d]$ pyren-6-ol $(200 \mathrm{mg}$, $0.567 \mathrm{mmol}$ ) was dissolved in a mixture of methanol:THF 
(1:1) (10 mL). $\mathrm{KOH}$ (47.7 mg in $5 \mathrm{~mL} \mathrm{H}_{2} \mathrm{O}, 0.850 \mathrm{mmol}, 1.5$ equiv.) was added dropwise by syringe. The mixture was stirred at $23{ }^{\circ} \mathrm{C}$ for 3 hours. The solvent was removed in vacuo and the crude product was loaded on a column (silica, length $10 \mathrm{~cm}, \varnothing 3 \mathrm{~cm}$ ) with chloroform as eluent. The product could be isolated at $R_{\mathrm{f}}=0.8$ in yield of $128 \mathrm{mg}(0.457 \mathrm{mmol}, 93 \%) .{ }^{1} \mathrm{H} \mathrm{NMR}$ $\left(300 \mathrm{MHz}, \mathrm{CDCl}_{3}\right): \delta=7.91\left(\mathrm{t},{ }^{3} J_{\mathrm{H}, \mathrm{H}}=7.7 \mathrm{~Hz}, 2 \mathrm{H}, \mathrm{H} 4\right), 8.03$ $\left(\mathrm{d},{ }^{3} J_{\mathrm{H}, \mathrm{H}}=8.7 \mathrm{~Hz}, 2 \mathrm{H}, \mathrm{H} 7 / \mathrm{H} 8\right), 8.14\left(\mathrm{~d},{ }^{3} J_{\mathrm{H}, \mathrm{H}}=8.7 \mathrm{~Hz}, 2 \mathrm{H}, \mathrm{H} 7 / \mathrm{H} 8\right)$, $8.35\left(\mathrm{dd},{ }^{3} J_{\mathrm{H}, \mathrm{H}}=7.8 \mathrm{~Hz},{ }^{3} J_{\mathrm{H}, \mathrm{H}}=0.9 \mathrm{~Hz}, 2 \mathrm{H}, \mathrm{H} 5\right), 8.90\left(\mathrm{dd},{ }^{3} J_{\mathrm{H}, \mathrm{H}}=\right.$ $\left.7.5 \mathrm{~Hz},{ }^{3} J_{\mathrm{H}, \mathrm{H}}=0.9 \mathrm{~Hz}, 2 \mathrm{H}, \mathrm{H} 3\right) \mathrm{ppm} ;{ }^{13} \mathrm{C} \mathrm{NMR}$ (75 MHz, $\mathrm{CDCl}_{3}$ ): $\delta=138.2(\mathrm{C}), 136.4(\mathrm{C}), 131.2(\mathrm{C}), 129.4(\mathrm{C}), 128.8(\mathrm{CH}), 127.6(\mathrm{CH})$, $126.9(\mathrm{CH}), 126.7(\mathrm{CH}), 124.2(\mathrm{C}), 88.5(\mathrm{C} \equiv \mathrm{C}), 93.0(\mathrm{C} \equiv \mathrm{CH})$, $68.9(\mathrm{C}-\mathrm{OH})$ ppm; IR $\left(\mathrm{CH}_{2} \mathrm{Cl}_{2}\right): \tilde{\nu}=3258(\mathrm{~s}, \mathrm{OH}), 2115(\mathrm{w}, \mathrm{C} \equiv \mathrm{C})$ $\mathrm{cm}^{-1}$; ESI-MS (MeOH) $m / z(\%)=279.09(100)[\mathrm{M}-\mathrm{H}]^{-}$; EA $\mathrm{C}_{21} \mathrm{H}_{12} \mathrm{O}\left(280.33 \mathrm{~g} \mathrm{~mol}^{-1}\right)$ : calc.: $\mathrm{C} 89.98, \mathrm{H} \mathrm{4.31}$; found: $\mathrm{C} 89.43$, $\mathrm{H} 4.54 \%$.

\section{Synthesis of $\left[\mathrm{Ru}\left(\eta^{5}-\mathrm{C}_{5} \mathrm{H}_{5}\right)(=\mathrm{C}=\mathrm{C}=(\mathrm{AO}))\left(\mathrm{PPh}_{3}\right)_{2}\right] \mathrm{PF}_{6}$ (1)}

A mixture of $\left[\operatorname{RuCl}\left(\eta^{5}-\mathrm{C}_{5} \mathrm{H}_{5}\right)\left(\mathrm{PPh}_{3}\right)_{2}\right](290 \mathrm{mg}, 0.400 \mathrm{mmol})$, 10-ethynyl-10-hydroxyanthracen-9-one (100 mg, $0.427 \mathrm{mmol})$ and $\mathrm{NH}_{4}\left[\mathrm{PF}_{6}\right](65.2 \mathrm{mg}, 0.400 \mathrm{mmol}$ ) was stirred for $1 \mathrm{~d}$. The deep-purple solution was filtered and the solvent removed under vacuum. The residue was dissolved in $\mathrm{CH}_{2} \mathrm{Cl}_{2}(10 \mathrm{~mL})$ and filtered into an excess of rapidly stirred $\mathrm{Et}_{2} \mathrm{O}$. The suspension was filtered and the purple precipitate was washed with cold $\mathrm{Et}_{2} \mathrm{O}$ $(3 \times 5 \mathrm{~mL})$ and dried in vacuo. The filtrate was worked up as before to give a second crop of the product, yield $235 \mathrm{mg}$ (0.223 mmol, 56\%). ${ }^{1} \mathrm{H}$ NMR $\left(\mathrm{CD}_{2} \mathrm{Cl}_{2}, 300.13 \mathrm{MHz}\right): \delta=8.31$ $\left(\mathrm{d},{ }^{3} J_{\mathrm{H}, \mathrm{H}}=7.8 \mathrm{~Hz}, 2 \mathrm{H}, \mathrm{AO}-\mathrm{H}\right), 8.00\left(\mathrm{t},{ }^{3} J_{\mathrm{H}, \mathrm{H}}=7.8 \mathrm{~Hz}, 2 \mathrm{H}, \mathrm{AO}-\mathrm{H}\right)$, $7.92\left(\mathrm{~d},{ }^{3} J_{\mathrm{H}, \mathrm{H}}=7.6 \mathrm{~Hz}, 2 \mathrm{H}, \mathrm{AO}-\mathrm{H}\right), 7.67\left(\mathrm{t},{ }^{3} J_{\mathrm{H}, \mathrm{H}}=7.6 \mathrm{~Hz}, 2 \mathrm{H}\right.$, $\mathrm{AO}-\mathrm{H}), 7.40\left(\mathrm{t},{ }^{3} J_{\mathrm{H}, \mathrm{H}}=7.0 \mathrm{~Hz}, 6 \mathrm{H}, p-\mathrm{PPh}_{3}\right), 7.22-7.12(\mathrm{~m}, 24 \mathrm{H}$, $\left.o-\mathrm{PPh}_{3}, m-\mathrm{PPh}_{3}\right), 5.27$ (s, 5H, Cp) ppm. ${ }^{13} \mathrm{C} \mathrm{NMR}\left(\mathrm{CD}_{2} \mathrm{Cl}_{2}, 75.48\right.$ $\mathrm{MHz}$ ): $\delta=293.5\left(\mathrm{~d},{ }^{2} J_{\mathrm{C}, \mathrm{P}}=27.2 \mathrm{~Hz}, \mathrm{C}-\alpha\right), 234.3(\mathrm{C}-\beta), 181.9(\mathrm{CO})$, 146.0 (C- $\gamma$ ), 134.5 (AO-C), 133.5 (d, $\left.{ }^{1} J_{\mathrm{C}, \mathrm{P}}=50.0 \mathrm{~Hz}, \mathrm{i}-\mathrm{PPh}_{3}\right), 132.3$ $\left(\mathrm{t},{ }^{2} J_{\mathrm{C}, \mathrm{P}}=10.5 \mathrm{~Hz}, o-\mathrm{PPh}_{3}\right), 131.7(\mathrm{AO}-\mathrm{CH}), 131.1(\mathrm{AO}-\mathrm{CH}), 130.1$ $\left(p-\mathrm{PPh}_{3}\right), 129.7(\mathrm{AO}-\mathrm{CH}), 128.4(\mathrm{AO}-\mathrm{CH}), 128.0\left(\mathrm{t},{ }^{2} J_{\mathrm{C}, \mathrm{P}}=10.5 \mathrm{~Hz}\right.$, $m-\mathrm{PPh}_{3}$ ), 127.4 (AO-C), 94.6 (Cp) ppm. ${ }^{31} \mathrm{P}$ NMR $\left(\mathrm{CD}_{2} \mathrm{Cl}_{2}, 121.50\right.$ $\mathrm{MHz}): \delta=47.12\left(\mathrm{~s}, \mathrm{PPh}_{3}\right),-144.48$ (sept, $\left.\mathrm{PF}_{6}\right)$ ppm. ESI-MS $\left(\mathrm{CH}_{2} \mathrm{Cl}_{2}\right): m / z(\%)=907.1827(100)[\mathrm{M}]^{+}$. IR $\left(\mathrm{CH}_{2} \mathrm{Cl}_{2}\right): \tilde{\nu}=1919$ $(\mathrm{C}=\mathrm{C}=\mathrm{C}), 1662(\mathrm{C}=\mathrm{O}), 1593(\mathrm{C}=\mathrm{C}) \mathrm{cm}^{-1} . \mathrm{EA} \mathrm{C}_{57} \mathrm{H}_{43} \mathrm{~F}_{6} \mathrm{OP}_{3} \mathrm{Ru}$ (1051.95 $\mathrm{g} \mathrm{mol}^{-1}$ ): calc.: $\mathrm{C}$ 65.08, $\mathrm{H}$ 4.12; found: $\mathrm{C}$ 65.22, $\mathrm{H} 4.14 \%$. TGA: $T_{\mathrm{d}} \approx 158{ }^{\circ} \mathrm{C}$. UV/Vis $\left(\mathrm{CH}_{2} \mathrm{Cl}_{2}\right): \lambda_{\max }$ in $\mathrm{nm}$ $\left(\varepsilon / \mathrm{dm}^{3} \mathrm{~mol}^{-1} \mathrm{~cm}^{-1}\right)=933$ (261), 574 (16 846), 372 (12 746).

\section{Synthesis of $\left[\mathrm{Ru}\left(\eta^{5}-\mathrm{C}_{5} \mathrm{H}_{5}\right)(=\mathrm{C}=\mathrm{C}=(\mathbf{P C O}))\left(\mathrm{PPh}_{3}\right)_{2}\right] \mathrm{PF}_{6}$ (2)}

A mixture of $\left[\mathrm{RuCl}\left(\eta^{5}-\mathrm{C}_{5} \mathrm{H}_{5}\right)\left(\mathrm{PPh}_{3}\right)_{2}\right](290 \mathrm{mg}, 0.400 \mathrm{mmol})$, 13-ethynyl-13-hydroxypentacen-6-one (140 mg, $0.420 \mathrm{mmol}$ ) and $\mathrm{NH}_{4}\left[\mathrm{PF}_{6}\right](65.2 \mathrm{mg}, 0.400 \mathrm{mmol})$ was stirred at reflux for $2 \mathrm{~d}$. The deep-blue solution was filtered and the solvent removed under vacuum. The residue was dissolved in $\mathrm{CH}_{2} \mathrm{Cl}_{2}$ $(10 \mathrm{~mL})$ and filtered into an excess of rapidly stirred $\mathrm{Et}_{2} \mathrm{O}$. The suspension was filtered and the dark blue precipitate was washed with $\mathrm{Et}_{2} \mathrm{O}(3 \times 5 \mathrm{~mL})$ and dried in vacuo. The filtrate was worked up as before to give a second crop of the product, yield $308 \mathrm{mg}$ (0.267 mmol, 67\%). ${ }^{1} \mathrm{H} \mathrm{NMR}\left(\mathrm{CD}_{2} \mathrm{Cl}_{2}, 300.13 \mathrm{MHz}\right)$ : $\delta=8.96(\mathrm{~s}, 2 \mathrm{H}, \mathrm{PCO}-\mathrm{H}), 8.59(\mathrm{~s}, 2 \mathrm{H}, \mathrm{PCO}-\mathrm{H}), 8.17\left(\mathrm{~d},{ }^{3} J_{\mathrm{H}, \mathrm{H}}=\right.$ $8.1 \mathrm{~Hz}, 2 \mathrm{H}, \mathrm{PCO}-\mathrm{H}), 7.90-7.83(\mathrm{~m}, 4 \mathrm{H}, \mathrm{PCO}-\mathrm{H}), 7.70(\mathrm{t}, 2 \mathrm{H}$, $\left.{ }^{3} J_{\mathrm{H}, \mathrm{H}}=9.0 \mathrm{~Hz}, \mathrm{PCO}-\mathrm{H}\right), 7.37-7.32\left(\mathrm{~m}, 6 \mathrm{H}, p-\mathrm{PPh}_{3}\right), 7.17-7.07$ $\left(\mathrm{m}, 24 \mathrm{H}, o-\mathrm{PPh}_{3}, m-\mathrm{PPh}_{3}\right), 5.26(\mathrm{~s}, 5 \mathrm{H}, \mathrm{Cp}) \mathrm{ppm} .{ }^{13} \mathrm{C} \mathrm{NMR}$ $\left(\mathrm{CD}_{2} \mathrm{Cl}_{2}, 75.48 \mathrm{MHz}\right): \delta=281.2\left(\mathrm{~d},{ }^{2} J_{\mathrm{C}, \mathrm{P}}=23.7 \mathrm{~Hz}, \mathrm{C}-\alpha\right), 208.8$ (C- $\beta$ ), 183.8 (CO), 144.8 (C- $\gamma$ ), 136.8 (PCO-C), 136.2 (PCO-C), $135.2\left(\mathrm{~d},{ }^{1} J_{\mathrm{CP}}=49.1 \mathrm{~Hz}, \mathrm{i}-\mathrm{PPh}_{3}\right), 134.8(\mathrm{PCO}-\mathrm{C}), 133.4\left(\mathrm{t},{ }^{2} J_{\mathrm{CP}}=\right.$ $\left.10.5 \mathrm{~Hz}, o-\mathrm{PPh}_{3}\right), 132.2$ (PCO-CH), 131.2 (PCO-CH), 131.1 $\left(p-\mathrm{PPh}_{3}\right), 130.8(\mathrm{PCO}-\mathrm{CH}), 130.7(\mathrm{PCO}-\mathrm{CH}), 130.3(\mathrm{PCO}-\mathrm{CH})$, 130.2 (PCO-CH), $129.0\left(\mathrm{t},{ }^{2} J_{\mathrm{CP}}=10.5 \mathrm{~Hz}, m-\mathrm{PPh}_{3}\right), 128.2$ (PCO-C), 93.6 (Cp) ppm. ${ }^{31} \mathrm{P}$ NMR $\left(\mathrm{CD}_{2} \mathrm{Cl}_{2}, 121.50 \mathrm{MHz}\right): \delta=46.93$ $\left(\mathrm{s}, \mathrm{PPh}_{3}\right),-144.53\left(\mathrm{qi}, \mathrm{PF}_{6}\right)$ ppm. ESI-MS $\left(\mathrm{CH}_{2} \mathrm{Cl}_{2}\right): m / z(\%)=$ 1007.22 (100) $[\mathrm{M}]^{+}$. IR $\left(\mathrm{CH}_{2} \mathrm{Cl}_{2}\right): \tilde{\nu}=1929(\mathrm{C}=\mathrm{C}=\mathrm{C}), 1679$ $(\mathrm{C}=\mathrm{O}), 1617(\mathrm{C}=\mathrm{C}), 1583(\mathrm{C}=\mathrm{C}) \mathrm{cm}^{-1} . \mathrm{EA} \mathrm{C}_{65} \mathrm{H}_{47} \mathrm{~F}_{6} \mathrm{OP}_{3} \mathrm{Ru}$ $\left(1152.07 \mathrm{~g} \mathrm{~mol}^{-1}\right)$ : calc.: $\mathrm{C}$ 67.77, $\mathrm{H}$ 4.11; found: $\mathrm{C} 67.40$, $\mathrm{H} 4.38 \%$. TGA: $T_{\mathrm{d}} \approx 152{ }^{\circ} \mathrm{C}$. UV/Vis $\left(\mathrm{CH}_{2} \mathrm{Cl}_{2}\right): \lambda_{\max }$ in $\mathrm{nm}$ $\left(\varepsilon / \mathrm{dm}^{3} \mathrm{~mol}^{-1} \mathrm{~cm}^{-1}\right)=940$ (262), 619 (20 759), 506 (5225), 402 (16 650).

\section{Synthesis of $\left[\mathrm{Ru}\left(\boldsymbol{\eta}^{5}-\mathrm{C}_{5} \mathrm{H}_{5}\right)(=\mathrm{C}=\mathrm{C}=(\mathrm{PyrPh}))\left(\mathrm{PPh}_{3}\right)_{2}\right] \mathrm{PF}_{6}$ (3)}

A mixture of $\left[\operatorname{RuCl}\left(\eta^{5}-\mathrm{C}_{5} \mathrm{H}_{5}\right)\left(\mathrm{PPh}_{3}\right)_{2}\right](580 \mathrm{mg}, 0.800 \mathrm{mmol})$, 1-phenyl-1-(pyren-1-yl)prop-2-yn-1-ol (300 mg, $0.886 \mathrm{mmol}$ ) and $\mathrm{NH}_{4}\left[\mathrm{PF}_{6}\right]$ (130 mg, $0.800 \mathrm{mmol}$ ) was stirred for $2 \mathrm{~d}$. The deep-red solution was filtered and the solvent removed under vacuum. The residue was dissolved in $\mathrm{CH}_{2} \mathrm{Cl}_{2}(20 \mathrm{~mL})$ and filtered into an excess of rapidly stirred $\mathrm{Et}_{2} \mathrm{O}$. The suspension was filtered and the black precipitate was washed with cold $\mathrm{Et}_{2} \mathrm{O}(3 \times 5 \mathrm{~mL})$ and dried in vacuo. The filtrate was worked up as before to give a second crop of the product, yield $258 \mathrm{mg}$ (0.224 mmol, 28\%). ${ }^{1} \mathrm{H}$ NMR $\left(\mathrm{CD}_{2} \mathrm{Cl}_{2}, 300.13 \mathrm{MHz}\right): \delta=8.38$ (d, $\left.{ }^{3} J_{\mathrm{H}, \mathrm{H}}=9.0 \mathrm{~Hz}, 1 \mathrm{H}, \mathrm{Pyr}-\mathrm{H}\right), 8.33\left(\mathrm{~d},{ }^{3} J_{\mathrm{H}, \mathrm{H}}=9.0 \mathrm{~Hz}, 1 \mathrm{H}, \mathrm{Pyr}-\mathrm{H}\right)$, 8.23-8.10 (m, 5H, Pyr-H), 7.83-7.75 (m, 5H, Pyr-H, o-Ph-H, $p-\mathrm{Ph}-\mathrm{H}), 7.46\left(\mathrm{t},{ }^{3} J_{\mathrm{H}, \mathrm{H}}=6.0 \mathrm{~Hz}, 2 \mathrm{H}, m-\mathrm{Ph}-\mathrm{H}\right), 7.26\left(\mathrm{t},{ }^{3} J_{\mathrm{H}, \mathrm{H}}=\right.$ $\left.6.0 \mathrm{~Hz}, 6 \mathrm{H}, p-\mathrm{PPh}_{3}\right), 7.09-6.89\left(\mathrm{~m}, 24 \mathrm{H}, o-\mathrm{PPh}_{3}, m-\mathrm{PPh}_{3}\right), 5.08$ (s, 5H, Cp) ppm. ${ }^{13} \mathrm{C}$ NMR $\left(\mathrm{CD}_{2} \mathrm{Cl}_{2}, 75.48 \mathrm{MHz}\right): \delta=302.0$ $\left(\mathrm{d},{ }^{2} J_{\mathrm{C}, \mathrm{P}}=26.3 \mathrm{~Hz}, \mathrm{C}-\alpha\right), 213.1(\mathrm{C}-\beta), 145.5(\mathrm{C}-\gamma), 142.2\left(\mathrm{Pyr}^{-\mathrm{C}^{1}}\right)$, 139.1 (Pyr-C), 135.9 (Pyr-C), 135.2 (d, ${ }^{1} J_{\mathrm{C}, \mathrm{P}}=50.0 \mathrm{~Hz}, \mathrm{i}-\mathrm{PPh}_{3}$ ), $135.1\left(\mathrm{~d},{ }^{1} J_{\mathrm{C}, \mathrm{P}}=50.2 \mathrm{~Hz}, \mathrm{i}-\mathrm{PPh}_{3}\right), 133.5\left(\mathrm{t},{ }^{2} J_{\mathrm{C}, \mathrm{P}}=9.8 \mathrm{~Hz}, o-\mathrm{PPh}_{3}\right)$, 133.2 (o-Ph-C), 133.4 (Pyr-C), 132.0 (Pyr-C), 131.2 (p-Ph-C), $131.2\left(p-\mathrm{PPh}_{3}\right), 130.0(\mathrm{Pyr}-\mathrm{C}), 128.7\left(\mathrm{t},{ }^{2} J_{\mathrm{C}, \mathrm{P}}=9.8 \mathrm{~Hz}, m-\mathrm{PPh}_{3}\right)$, 125.6 (Pyr-C), 93.9 (Cp) ppm. ${ }^{31} \mathrm{P} \mathrm{NMR}\left(\mathrm{CD}_{2} \mathrm{Cl}_{2}, 121.50 \mathrm{MHz}\right)$ : $\delta=45.95\left(\mathrm{~s}, \mathrm{PPh}_{3}\right),-144.52$ (sept, $\left.\mathrm{PF}_{6}\right)$ ppm. ESI-MS $\left(\mathrm{CH}_{2} \mathrm{Cl}_{2}\right)$ : $m / z(\%)=1005.23(100)[\mathrm{M}]^{+} . \mathrm{IR}\left(\mathrm{CH}_{2} \mathrm{Cl}_{2}\right): \tilde{\nu}=1931(\mathrm{C}=\mathrm{C}=\mathrm{C})$, $1653(\mathrm{C}=\mathrm{C}), 1593(\mathrm{C}=\mathrm{C}) \mathrm{cm}^{-1} . \mathrm{EA} \mathrm{C}_{66} \mathrm{H}_{49} \mathrm{~F}_{6} \mathrm{P}_{3} \mathrm{Ru}\left(1150.10 \mathrm{~g} \mathrm{~mol}^{-1}\right)$ : calc.: C 68.93, H 4.29; found: C 68.49, H 4.20\%. TGA: $T_{\mathrm{d}} \approx$ $238{ }^{\circ} \mathrm{C}$. UV/Vis $\left(\mathrm{CH}_{2} \mathrm{Cl}_{2}\right): \lambda_{\max }$ in $\mathrm{nm}\left(\varepsilon / \mathrm{dm}^{3} \mathrm{~mol}^{-1} \mathrm{~cm}^{-1}\right)=821$ (924), 587 (27 563), 479 (32 469).

\section{Synthesis of $\left[\mathrm{Ru}\left(\eta^{5}-\mathrm{C}_{5} \mathrm{H}_{5}\right)(=\mathrm{C}=\mathrm{C}=(\mathrm{FN}))\left(\mathrm{PPh}_{3}\right)_{2}\right] \mathbf{P F}_{6}$ (4)}

A mixture of $\left[\operatorname{RuCl}\left(\eta^{5}-\mathrm{C}_{5} \mathrm{H}_{5}\right)\left(\mathrm{PPh}_{3}\right)_{2}\right](363 \mathrm{mg}, 0.500 \mathrm{mmol})$, 9-ethynyl-9-fluorenyl (107 $\mathrm{mg}, 0.520 \mathrm{mmol})$ and $\mathrm{NH}_{4}\left[\mathrm{PF}_{6}\right]$ (81.5 $\mathrm{mg}, 0.500 \mathrm{mmol}$ ) was stirred for $1 \mathrm{~d}$. The deep-pink solution was filtered and the solvent removed under vacuum. The residue was dissolved in $\mathrm{CH}_{2} \mathrm{Cl}_{2}(10 \mathrm{~mL})$ and filtered into an excess of rapidly stirred $\mathrm{Et}_{2} \mathrm{O}$. The suspension was filtered and the purple precipitate was washed with cold $\mathrm{Et}_{2} \mathrm{O}(3 \times 5 \mathrm{~mL})$ 
and dried in vacuo. The filtrate was worked up as before to give a second crop of the product, yield $343 \mathrm{mg}$ (0.335 mmol, 67\%). ${ }^{1} \mathrm{H}$ NMR $\left(\mathrm{CD}_{2} \mathrm{Cl}_{2}, 300.13 \mathrm{MHz}\right): \delta=7.64\left(\mathrm{t},{ }^{3} J_{\mathrm{H}, \mathrm{H}}=7.5 \mathrm{~Hz}, 2 \mathrm{H}\right.$, $\mathrm{FN}-\mathrm{H}), 7.46\left(\mathrm{~d},{ }^{3} \mathrm{~J}_{\mathrm{H}, \mathrm{H}}=7.5 \mathrm{~Hz}, 2 \mathrm{H}, \mathrm{FN}-\mathrm{H}\right), 7.42-7.37(\mathrm{~m}, 4 \mathrm{H}$, $\mathrm{FN}-\mathrm{H}$ ), 7.26-7.13 (m, 24H, $\left.o-\mathrm{PPh}_{3}, m-\mathrm{PPh}_{3}, p-\mathrm{PPh}_{3}\right), 5.16$ (s, 5H, Cp) ppm. ${ }^{13} \mathrm{C} \mathrm{NMR}\left(\mathrm{CD}_{2} \mathrm{Cl}_{2}, 75.48 \mathrm{MHz}\right): \delta=294.7\left(\mathrm{~d},{ }^{2} J_{\mathrm{C}, \mathrm{P}}=17.5 \mathrm{~Hz}\right.$, C- $\alpha$ ), 213.4 (C- $\beta$ ), 145.9 (C- $\gamma$ ), 142.0 (FN-C), 135.4 (FN-C), 134.2 $(\mathrm{FN}-\mathrm{CH}), 134.9\left(\mathrm{~d},{ }^{1} J_{\mathrm{C}, \mathrm{P}}=49.8 \mathrm{~Hz}, \mathrm{i}-\mathrm{PPh}_{3}\right), 133.7\left(\mathrm{t},{ }^{2} J_{\mathrm{C}, \mathrm{P}}=10.5 \mathrm{~Hz}\right.$, $\left.o-\mathrm{PPh}_{3}\right), 131.2\left(p-\mathrm{PPh}_{3}\right), 130.0(\mathrm{FN}-\mathrm{CH}), 129.2\left(\mathrm{t},{ }^{2} J_{\mathrm{C}, \mathrm{P}}=10.5 \mathrm{~Hz}\right.$, $m-\mathrm{PPh}_{3}$ ), 124.4 (FN-CH), 122.1 (FN-CH), 94.8 (Cp) ppm. ${ }^{31} \mathrm{P}$ NMR $\left(\mathrm{CD}_{2} \mathrm{Cl}_{2}, 121.50 \mathrm{MHz}\right): \delta=47.60\left(\mathrm{~s}, \mathrm{PPh}_{3}\right),-144.48$ (sept, $\left.\mathrm{PF}_{6}\right) \mathrm{ppm}$. ESI-MS $\left(\mathrm{CH}_{2} \mathrm{Cl}_{2}\right): m / z(\%)=879.13(100)[\mathrm{M}]^{+}$. IR $\left(\mathrm{CH}_{2} \mathrm{Cl}_{2}\right)$ : $\tilde{\nu}=1939(\mathrm{C}=\mathrm{C}=\mathrm{C}), 1600(\mathrm{C}=\mathrm{C}) \mathrm{cm}^{-1}$. $\mathrm{EA} \quad \mathrm{C}_{56} \mathrm{H}_{43} \mathrm{~F}_{6} \mathrm{P}_{3} \mathrm{Ru}$ (1023.94 $\left.\mathrm{g} \mathrm{mol}^{-1}\right)$ : calc.: $\mathrm{C}$ 65.69, $\mathrm{H}$ 4.23; found: $\mathrm{C}$ 66.02, $\mathrm{H} 4.32 \%$. TGA: $T_{\mathrm{d}} \approx 219{ }^{\circ} \mathrm{C}$. UV/Vis $\left(\mathrm{CH}_{2} \mathrm{Cl}_{2}\right): \lambda_{\max }$ in $\mathrm{nm}$ $\left(\varepsilon / \mathrm{dm}^{3} \mathrm{~mol}^{-1} \mathrm{~cm}^{-1}\right)=920$ (183), 535 (26 705), 397 (11343).

\section{Synthesis of $\left[\mathrm{Ru}\left(\eta^{5}-\mathrm{C}_{5} \mathrm{H}_{5}\right)(=\mathrm{C}=\mathrm{C}=(\mathrm{BPyr}))\left(\mathrm{PPh}_{3}\right)_{2}\right] \mathbf{P F}_{6}$ (5)}

A mixture of $\left[\operatorname{RuCl}\left(\eta^{5}-\mathrm{C}_{5} \mathrm{H}_{5}\right)\left(\mathrm{PPh}_{3}\right)_{2}\right](109 \mathrm{mg}, 0.150 \mathrm{mmol})$, 6-ethynyl-6H-benzo $[c d]$ pyren-6-ol $(50.0 \mathrm{mg}, 0.178 \mathrm{mmol})$ and $\mathrm{NH}_{4}\left[\mathrm{PF}_{6}\right]$ (24.4 mg, $0.150 \mathrm{mmol}$ ) was stirred for $2 \mathrm{~d}$. The deep-turquoise solution was filtered and the solvent removed under vacuum. The residue was dissolved in $\mathrm{CH}_{2} \mathrm{Cl}_{2}(10 \mathrm{~mL})$ and filtered into an excess of rapidly stirred $\mathrm{Et}_{2} \mathrm{O}$. The suspension was filtered and the turquoise precipitate was washed with cold $\mathrm{Et}_{2} \mathrm{O}$ $(3 \times 5 \mathrm{~mL})$ and dried in vacuo. The filtrate was worked up as before to give a second crop of the product, yield $97.0 \mathrm{mg}$ (0.088 mmol, 59\%). ${ }^{1} \mathrm{H} \mathrm{NMR}\left(\mathrm{CD}_{2} \mathrm{Cl}_{2}, 300.13 \mathrm{MHz}\right): \delta=8.69$ $\left(\mathrm{d},{ }^{3} J_{\mathrm{H}, \mathrm{H}}=6.0 \mathrm{~Hz}, 2 \mathrm{H}, \mathrm{BPyr}-\mathrm{H}\right), 8.64\left(\mathrm{~d},{ }^{3} J_{\mathrm{H}, \mathrm{H}}=9.0 \mathrm{~Hz}, 2 \mathrm{H}, \mathrm{BPyr}-\mathrm{H}\right)$, $8.38\left(\mathrm{~d},{ }^{3} J_{\mathrm{H}, \mathrm{H}}=6.0 \mathrm{~Hz}, 2 \mathrm{H}, \mathrm{BPyr}-\mathrm{H}\right), 8.14\left(\mathrm{~d},{ }^{3} \mathrm{~J}_{\mathrm{H}, \mathrm{H}}=9.0 \mathrm{~Hz}, 2 \mathrm{H}\right.$, BPyr-H), $7.83\left(\mathrm{t},{ }^{3} J_{\mathrm{H}, \mathrm{H}}=6.0 \mathrm{~Hz}, 2 \mathrm{H}, \mathrm{BPyr}-\mathrm{H}\right), 7.36\left(\mathrm{t},{ }^{3} J_{\mathrm{H}, \mathrm{H}}=9.0 \mathrm{~Hz}\right.$, $\left.6 \mathrm{H}, p-\mathrm{PPh}_{3}\right), 7.36\left(\mathrm{t},{ }^{3} J_{\mathrm{H}, \mathrm{H}}=9.0 \mathrm{~Hz}, 6 \mathrm{H}, p-\mathrm{PPh}_{3}\right), 7.31-7.25(\mathrm{~m}, 12 \mathrm{H}$, $\left.m-\mathrm{PPh}_{3}\right), 7.18\left(\mathrm{t},{ }^{3} J_{\mathrm{H}, \mathrm{H}}=9.0 \mathrm{~Hz}, 12 \mathrm{H}, o-\mathrm{PPh}_{3}\right), 5.07$ (s, 5H, Cp) ppm. ${ }^{13} \mathrm{C} \mathrm{NMR}\left(\mathrm{CD}_{2} \mathrm{Cl}_{2}, 75.48 \mathrm{MHz}\right): \delta=286.5\left(\mathrm{~d},{ }^{2} J_{\mathrm{C}, \mathrm{P}}=22.7 \mathrm{~Hz}, \mathrm{C}-\alpha\right)$, 207.0 (C- $\beta$ ), 143.3 (C- $\gamma$ ), 138.8 (BPyr-C), 136.3 (BPyr-C), 136.2 (BPyr-CH), 135.9 (d, ${ }^{1} J_{\mathrm{C}, \mathrm{P}}=40.0 \mathrm{~Hz}, \mathrm{i}-\mathrm{PPh}_{3}$ ), 134.0 (BPyr-C), $133.7\left(\mathrm{t},{ }^{2} J_{\mathrm{CP}}=10.5 \mathrm{~Hz}, o-\mathrm{PPh}_{3}\right), 132.5(\mathrm{BPyr}-\mathrm{C}), 130.7\left(p-\mathrm{PPh}_{3}\right)$, 130.3 (BPyr-CH), $129.3(\mathrm{BPyr}-\mathrm{CH}), 128.8\left(\mathrm{t},{ }^{2} J_{\mathrm{C}, \mathrm{P}}=10.5 \mathrm{~Hz}\right.$, $m$ - $\mathrm{PPh}_{3}$ ), 125.8 (BPyr-C), 91.8 (Cp) ppm. ${ }^{31} \mathrm{P}$ NMR $\left(\mathrm{CD}_{2} \mathrm{Cl}_{2}\right.$, 121.50 MHz): $\delta=50.27\left(\mathrm{~s}, \mathrm{PPh}_{3}\right),-143.27$ (sept, $\left.\mathrm{PF}_{6}\right)$ ppm. ESIMS $\left(\mathrm{CH}_{2} \mathrm{Cl}_{2}\right): m / z(\%)=953.20(100)[\mathrm{M}]^{+}$. IR $\left(\mathrm{CH}_{2} \mathrm{Cl}_{2}\right): \tilde{\nu}=1942$ $(\mathrm{C}=\mathrm{C}=\mathrm{C}), 1605(\mathrm{C}=\mathrm{C}), 1570(\mathrm{C}=\mathrm{C}) \mathrm{cm}^{-1} . \mathrm{EA} \mathrm{C}_{62} \mathrm{H}_{45} \mathrm{~F}_{6} \mathrm{P}_{3} \mathrm{Ru}$ (1098.02 $\mathrm{g} \mathrm{mol}^{-1}$ ): calc.: $\mathrm{C}$ 67.82, $\mathrm{H}$ 4.13; found: $\mathrm{C}$ 67.44, $\mathrm{H} 4.52 \%$. TGA: $T_{\mathrm{d}} \approx 185{ }^{\circ} \mathrm{C}$. UV/Vis $\left(\mathrm{CH}_{2} \mathrm{Cl}_{2}\right): \lambda_{\max }$ in $\mathrm{nm}$ $\left(\varepsilon / \mathrm{dm}^{3} \mathrm{~mol}^{-1} \mathrm{~cm}^{-1}\right)=928$ (235), 733 (45 592), 681 (44334), 523 (8962), 445 (5576).

\section{$\mathrm{X}$-ray structure determination}

The structure determination for $\mathbf{1}$ and $\mathbf{2}$ were carried out on a Bruker-Nonius Kappa-CCD diffractometer. For the structure of 5 X-ray intensity data was collected on an Agilent Supernova Dual Source diffractometer equipped with an Atlas S2 CCD detector. In all cases Mo-K $\alpha$ radiation $(\lambda=0.71073 \AA)$ was used. Single crystals of 1, 2 and 5 were coated with perfluoropolyether, picked with a glass fiber or loop, and immediately mounted in the nitrogen cold gas stream of the diffractometer.
The structures were solved by using direct methods and refined with full-matrix least squares against $F^{2}$ (SHELX-97). ${ }^{64}$ A weighting scheme was applied in the last steps of the refinement with $w=1 /\left[\sigma^{2}\left(F_{\mathrm{o}}{ }^{2}\right)+(a P)^{2}+b P\right]$ and $P=\left[2 F_{\mathrm{c}}{ }^{2}+\max \left(F_{\mathrm{o}}{ }^{2}, 0\right)\right] / 3$. The hydrogen atoms were included in their calculated positions and refined in a riding model. The asymmetric unit of 1 contains one disordered diethyl ether molecule that was refined in a 1:1 ratio on two positions. The asymmetric unit of 2 contains one acetone and one diethyl ether molecule and in case of complex 5 one dichloromethane and half a molecule of disordered $n$-hexane were found. Since it was not possible to resolve the disorder of this $n$-hexane, SQUEEZE was applied in case of 5. ${ }^{65,66}$ The structure pictures were prepared with the program Mercury. ${ }^{67}$

\section{Calculations}

All density-functional theory (DFT)-calculations were carried out by using the Jaguar 7.7.107 software running on Linux 2.6.18-238.el5 SMP $\left(\times 86 \_64\right)$ on two AMD Phenom II X6 1090T processor workstations (Beowulf-cluster) parallelized with OpenMPI. ${ }^{68}$ The X-ray crystal structure of 2 was used as starting geometry. Complete geometry optimization was carried out on the implemented LACVP* (Hay-Wadt effective core potential (ECP) basis on heavy atoms, N31G6* for all other atoms) basis set and with the B3LYP density functional. The calculated structure was proven to be a true minima by the absence of large imaginary frequencies. Orbital plots were obtained using Maestro 9.1.207, the graphical interface of Jaguar. UV/Vis transitions were obtained by time dependent (TD) DFT-calculations on the geometry of the minimized structure.

\section{Conclusions}

Carbon-rich, cationic Cp-ruthenium allenylidene complexes bearing a range of polyaromatic moieties have been synthesized. These complexes show significant $\pi$-stacking in the solid-state structures, especially 1 and 2 , and in solution $\pi$-stacking interactions were established by UV/Vis experiments with pyrene and the associated Job's plots. High extinction coefficients in the visible spectrum, as well as absorptions in the near-IR, demonstrated by the complexes suggest potential applications in DSSCs, particularly since these complexes are very stable according to TGA analyses. The CV data implies significant electron-acceptor potential of the complexes. Especially, complex 2 shows a staircase $\pi$-stacking in solid state that might be a good design for future metal-tuned FETs or "organic" metal-semiconductor field-effect transistors (OMESFETs). Future work will focus on the question whether SWCNTs can be decorated with such complexes by $\pi$-interactions.

\section{Acknowledgements}

This work was generously supported by 'Solar Technologies go Hybrid', an initiative of the Bavarian State Ministry for Science, Research and Art. Funding of a Bruker AVANCE III HD $400 \mathrm{MHz}$ spectrometer and a Bruker AVANCE III HD $600 \mathrm{MHz}$ spectrometer as well as a Super Nova A S2 (Dual) diffractometer with 
Atlas S2 CCD detector and Nova (Cu) and Mova (Mo) X-ray sources by the German Research Council (DFG) is gratefully acknowledged.

\section{Notes and references}

1 D. Jain, A. Saha and A. A. Marti, Chem. Commun., 2011, 47, 2246-2248.

2 J. Bartelmess, B. Ballesteros, G. de la Torre, D. Kiessling, S. Campidelli, M. Prato, T. Torres and D. M. Guldi, J. Am. Chem. Soc., 2010, 132, 16202-16211.

3 J. Yu, S. Mathew, B. S. Flavel, M. R. Johnston and J. G. Shapter, J. Am. Chem. Soc., 2008, 130, 8788-8796.

4 Q. Miao, Synlett, 2012, 326-336.

5 Z. Liang, Q. Tang, J. Liu, J. Li, F. Yan and Q. Miao, Chem. Mater., 2010, 22, 6438-6443.

6 A. R. Murphy and J. M. J. Fréchet, Chem. Rev., 2007, 107, 1066-1096.

7 J. E. Anthony, Angew. Chem., Int. Ed., 2008, 47, 452-483.

8 J. E. Anthony, Chem. Rev., 2006, 106, 5028-5048.

9 Q. Tang, J. Liu, H. S. Chan and Q. Miao, Chem. - Eur. J., 2009, 15, 3965-3969.

10 S. H. Etschel, A. R. Waterloo, J. T. Margraf, A. Y. Amin, F. Hampel, C. M. Jager, T. Clark, M. Halik and R. R. Tykwinski, Chem. Commun., 2013, 49, 6725-6727.

11 D. Lehnherr, A. H. Murray, R. McDonald and R. R. Tykwinski, Angew. Chem., Int. Ed., 2010, 49, 6190-6194.

12 S. Guesmi, D. Touchard and P. H. Dixneuf, Chem. Commun., 1996, 2773-2774.

13 S. K. Costuas, D. Touchard, J.-Y. Saillard, S. Golhen and P. H. Dixneuf, J. Am. Chem. Soc., 2004, 126, 4072-4073.

14 S. Rigaut, D. Touchard and P. H. Dixneuf, Coord. Chem. Rev., 2004, 248, 1585-1601.

15 S. Rigaut, O. Maury, D. Touchard and P. H. Dixneuf, Chem. Commun., 2001, 373-374.

16 N. Mantovani, M. Brugnati, L. Gonsalvi, E. Grigiotti, F. Laschi, L. Marvelli, M. Peruzzini, G. Reginato, R. Rossi and P. Zanello, Organometallics, 2005, 24, 405-418.

17 F. Paul and C. Lapinte, Coord. Chem. Rev., 1998, 178180(part 1), 431-509.

18 E. O. Fischer, H. J. Kalder, A. Frank, F. H. Köhler and G. Huttner, Angew. Chem., 1976, 88, 683-684.

19 E. O. Fischer and A. Maasböl, Angew. Chem., 1964, 76, 645.

20 H. Berke, Angew. Chem., 1976, 88, 684-685.

21 M. I. Bruce, Chem. Rev., 1998, 98, 2797-2858.

22 R. Castarlenas, C. Vovard, C. Fischmeister and P. H. Dixneuf, J. Am. Chem. Soc., 2006, 128, 4079-4089.

23 A. Fürstner, M. Liebl, C. W. Lehmann, M. Picquet, R. Kunz, C. Bruneau, D. Touchard and P. H. Dixneuf, Chem. - Eur. J, 2000, 6, 1847-1857.

24 D. Touchard and P. H. Dixneuf, Coord. Chem. Rev., 1998, 178-180(part 1), 409-429.

25 V. Cadierno and J. Gimeno, Chem. Rev., 2009, 109, 3512-3560.

26 J. W. Herndon, Coord. Chem. Rev., 2013, 257, 2899-3003.
27 I. García de la Arada, J. Díez, M. P. Gamasa and E. Lastra, Organometallics, 2015, 34, 1345-1353.

28 E. Bustelo, M. Jiménez-Tenorio, M. C. Puerta and P. Valerga, Organometallics, 2007, 26, 4300-4309.

29 S. Conejero, J. Díez, M. P. Gamasa and J. Gimeno, Organometallics, 2004, 23, 6299-6310.

30 M. Lichtenheldt, S. Kress and S. Blechert, Molecules, 2012, 17, 5177.

31 A. Antonucci, M. Bassetti, C. Bruneau, P. H. Dixneuf and C. Pasquini, Organometallics, 2010, 29, 4524-4531.

32 M. J. Queensen, N. P. Rath and E. B. Bauer, Organometallics, 2014, 33, 5052-5065.

33 C. E. Diesendruck, E. Tzur and N. G. Lemcoff, Eur. J. Inorg. Chem., 2009, 4185-4203.

34 X. Sauvage, Y. Borguet, G. Zaragoza, A. Demonceau and L. Delaude, Adv. Synth. Catal., 2009, 351, 441-455.

35 H. Kopf, B. Holzberger, C. Pietraszuk, E. Hübner and N. Burzlaff, Organometallics, 2008, 27, 5894-5905.

36 R. Castarlenas, C. Fischmeister, C. Bruneau and P. H. Dixneuf, J. Mol. Catal. A: Chem., 2004, 213, 31-37.

37 B. Cetinkaya, S. Demir, I. Ozdemir, L. Toupet, D. Semeril, C. Bruneau and P. H. Dixneuf, New J. Chem., 2001, 25, 519-521.

38 A. Fürstner, A. Furstner, M. Picquet, C. Bruneau and P. H. Dixneuf, Chem. Commun., 1998, 1315-1316.

39 D. F. Alkhaleeli, K. J. Baum, J. M. Rabus and E. B. Bauer, Catal. Commun., 2014, 47, 45-48.

40 S. Csihony, C. Fischmeister, C. Bruneau, I. T. Horvath and P. H. Dixneuf, New J. Chem., 2002, 26, 1667-1670.

41 M. Saoud, A. Romerosa and M. Peruzzini, Organometallics, 2000, 19, 4005-4007.

42 S. M. Maddock and M. G. Finn, Angew. Chem., Int. Ed., 2001, 40, 2138-2141.

43 D. A. Valyaev, M. G. Peterleitner, O. V. Semeikin, K. I. Utegenov, N. A. Ustynyuk, A. Sournia-Saquet, N. Lugan and G. Lavigne, J. Organomet. Chem., 2007, 692, 3207-3211.

44 N. E. Kolobova, L. L. Ivanov, O. S. Zhvanko, O. M. Khitrova, A. S. Batsanov and Y. T. Struchkov, J. Organomet. Chem., 1984, 262, 39-47.

45 D. Touchard, N. Pirio and P. H. Dixneuf, Organometallics, 1995, 14, 4920-4928.

46 C. Cosset, I. Del Rio and H. Le Bozec, Organometallics, 1995, 14, 1938-1944.

47 R. Le Lagadec, E. Roman, L. Toupet, U. Mueller and P. H. Dixneuf, Organometallics, 1994, 13, 5030-5039.

48 R. Dussel, D. Pilette, P. H. Dixneuf and W. P. Fehlhammer, Organometallics, 1991, 10, 3287-3291.

49 F. Strinitz, J. Tucher, J. A. Januszewski, A. R. Waterloo, P. Stegner, S. Förtsch, E. Hübner, R. R. Tykwinski and N. Burzlaff, Organometallics, 2014, 33, 5129-5144.

50 F. Strinitz, A. Waterloo, J. Tucher, E. Hübner, R. R. Tykwinski and N. Burzlaff, Eur. J. Inorg. Chem., 2013, 5181-5186.

51 H. Kopf, C. Pietraszuk, E. Hübner and N. Burzlaff, Organometallics, 2006, 25, 2533-2546.

52 J. P. Selegue, Organometallics, 1982, 1, 217-218.

53 M. Tamm, T. Jentsch and W. Werncke, Organometallics, 1997, 16, 1418-1424. 
54 M. I. Bruce, P. J. Low and E. R. T. Tiekink, J. Organomet. Chem., 1999, 572, 3-10.

55 F. Strinitz, PhD thesis, University of Erlangen-Nürnberg, 2014.

56 P. Thordarson, Chem. Soc. Rev., 2011, 40, 1305-1323.

57 R. F. Winter, Eur. J. Inorg. Chem., 1999, 2121-2126.

58 S. Hartmann, R. F. Winter, B. Sarkar and F. Lissner, Dalton Trans., 2004, 3273-3282.

59 S. Rigaut, J. Perruchon, S. Guesmi, C. Fave, D. Touchard and P. H. Dixneuf, Eur. J. Inorg. Chem., 2005, 447-460.

60 G. A. Koutsantonis, P. A. Schauer and B. W. Skelton, Organometallics, 2011, 30, 2680-2689.

61 S. H. Yoo, J. M. Kum and S. O. Cho, Nanoscale Res. Lett., 2011, 6, 1-7.
62 M. I. Bruce, C. Hameister, A. G. Swincer, R. C. Wallis and S. D. Ittel, Inorganic Syntheses, John Wiley \& Sons, Inc., 2007, pp. 270-272.

63 J. Morgenthaler and C. Rüchardt, Eur. J. Org. Chem., 1999, 2219-2230.

64 G. Sheldrick, Acta Crystallogr., Sect. A: Found. Crystallogr., 2008, 64, 112-122.

65 P. van der Sluis and A. L. Spek, Acta Crystallogr., 1990, A46, 194-201.

66 A. L. Spek, J. Appl. Crystallogr., 2003, 36, 7-13.

67 C. F. Macrae, P. R. Edgington, P. McCabe, E. Pidcock, G. P. Shields, R. Taylor, M. Towler and J. van de Streek, J. Appl. Crystallogr., 2006, 39, 453-457.

68 Jaguar, version 7.7, Schrodinger, LLC, New York, NY, 2010. 